\title{
The Geographical Extent of Azania
}

Felix Chami

\begin{abstract}
The Romans identified East Africa as Azania. The Chinese as Zezan. The metropolis of Rhapta was indicated to be the capital of Azania. In recent times a controversy emerged as to the location of Azania and Rhapta. A discussion has also occurred regarding the kind of people who settled in Azania. Whereas some scholars agree that the core of Azania was in East Africa modern, the geographical extent of Azania is in question. Archaeological, historical, and linguistic data have been used to suggest Azania extended from the coast of East Africa to the Great Lakes region, central Africa and South Africa. It is also argued that the people of Azania were Bantu speakers who were farming and smelting iron. It is therefore justifiable for the people of the larger region of South Africa to East Africa to name themselves Azanians.
\end{abstract}

Keywords: Azania, Bantu, Cushitic, Early Iron Age, East Africa, Rhapta, Roman

\section{Azania and its Historical Background}

Azania is a region which is accepted by most scholars to be a name used by the Romans for the territory of East Africa which they visited and controlled in the first four centuries CE. Most scholars also agree it was ancient East Africa (Casson 1989 Chami 1999b; Datoo 1970; Horton 1996; Huntingford 1980; Kirwan 1986; McLaughlin 2018; Schoff 1912). Azania was first mentioned by Elder Pliny in the first century $\mathrm{CE}$ in connection to trade in spices such as cinnamon and cassia. Different from his predecessors who wrote from the time of Herodotus. Pliny claimed that those spices had 
been reaching the Red Sea and the Mediterranean region from Azania (Chami 2017: 526; Pliny/Rackam 1961: 12.42-43, 12.85-98). Miller (1969) has probably provided the best discussion of the East African Azania concerning Pliny's report.

The second mentioning and elucidation of Azania are that of the first century CE by Periplus of the Eritrean Sea which is a document written in Latin by an anonymous sailor who provided a sailing and trading guide to Azania and India (Miller 1969). Claudia Ptolemy of the third century CE did provide more information about Azania collected from those who had been to Azania (see further in this article). Ptolemy also provided a map of Africa showing the location of Azania. In his report, he suggested the extent to which Azania could have reached the Great Lakes region and the Mozambican coast and Madagascar by reporting about different Roman skippers' visitations to those regions (Carry and Warmington 1963; Chami 2017: 527; Lacroix 1998).

Cosmas Indicopleitus provided anecdotal information about Azania in the sixth century CE. using the term Zingion rather than Azania (Freeman-Grenville 1962). The term had been used before by Pliny the Elder in connection with Azania. It is this same term that came to be used by Arabs and Chinese afterwards as Zanj/ Zingi to mean the coast of East Africa and its people (Chittick 1975; Trimingham 1975). The Chinese are also known to have had visited East Africa in the early centuries CE. They claimed to have circumnavigated Africa from Azania via southern Africa to Rome. They identified East Africa as Zezan (Hill 2004).

I have conjectured the meaning of the name Azania elsewhere (Chami 2006: 73). The word could have had meant a large mass of water or what came to be known as the Indian Ocean. This thinking is predicated on the fact that some Bantu speakers identify masses of water today like lakes as either $z a$ or $z i$. It is from this word we get names of many lakes in the Bantu speaking region like Nyanza for Lake Victoria, Nyasa for lake Malawi, and others, such as Eyasi, Zakwati, Misasa, and so on. A lake itself is either referred to as ziwa or just $s a$. Whereas the ancient people of the coast of East Africa referred to themselves as people of the then Indian Ocean or Azania, in the later historical period they identified themselves as Zanch, meaning people of the land/inch of the Indian Ocean or Za. Actually, the meaning to the word Swahili, which came to be 
the name of the people of the coast of East Africa after $1200 \mathrm{CE}$, is sawahil in Arabic being Sahel pl. sawahil, adj. sawahli or sawahili, meaning the coast or littoral (Chami 1998: 214) This name matched the earlier Bantu speakers' word Zanji.

\section{Key Issues in the Roman Reports on Azania}

\section{The Ports}

First, the metropolis of Azania. There were several trading ports or emporium during the first century CE. The most important one for the Periplus report was Rhapta which is portrayed probably as the capital of Azania (McLaughlin 2018). Other mentioned ports include Essina and Toniki (Casson 1989: 134). In the third century CE, Ptolemy recognises Rhapta and Toniki as the metropolis. The location of these trading ports has been a bit controversial. However, both early reports recognise Rhapta as having had been located at a bank of a navigable river at a day's sail southward from an island only thirty miles offshore the mainland. Most scholars agree this to be Zanzibar and hence agree Rhapta was located at the Rufiji River (Chittick 1982; Lacroix 1998). Ptolemy recognises the people of the Rhapta area in the area of this river as Rafiji Ethiopes/ black people. The name given to these people is very likely a corruption of the modern-day Rufiji River. This is also the name of the modern people in that area of the river. The southern island of three islands of Azania in Ptolemy's map is Mafiaco. This is also corruption, of the modern-day Mafia Island which is offshore the delta of the Rufiji River (Lacroix 1998). My continued search for the lost metropolis of Rhapta on the Mafia Island and the Rufiji Delta area is yielding some positive results (Figures 1-3; Shikoni et al. 2019).

\section{Trade}

Imports of Azania included iron objects, wine, and grains. Exports included ivory, rhinoceros horn, tortoise shells, and coconut oil (Casson 1989, 1980).

\section{Peopling}

Apart from a note in the Periplus document that the people of Rhapta were big-bodied and that they were agriculturalist/tillers of 


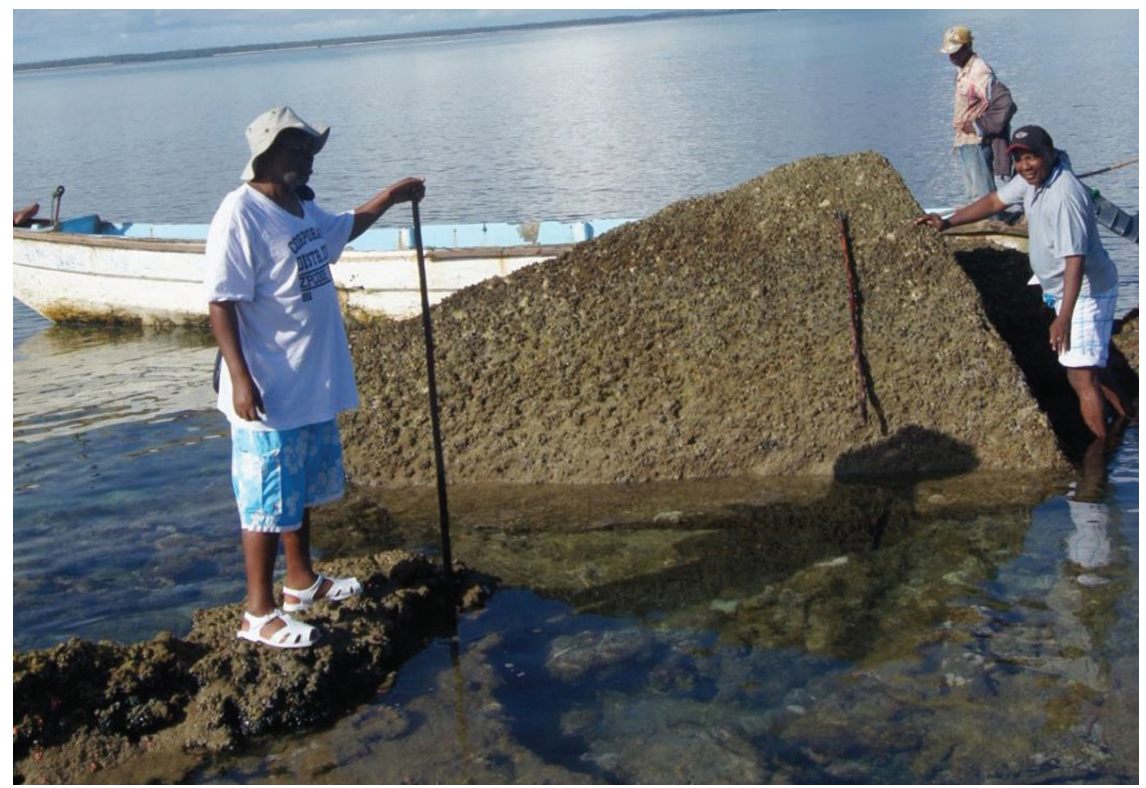

Figure 1. The author at the boulders of ancient walls which could have fenced Rhapta. (Photo by Dr Christowaja Ntandu, Tanzania Antiquity)

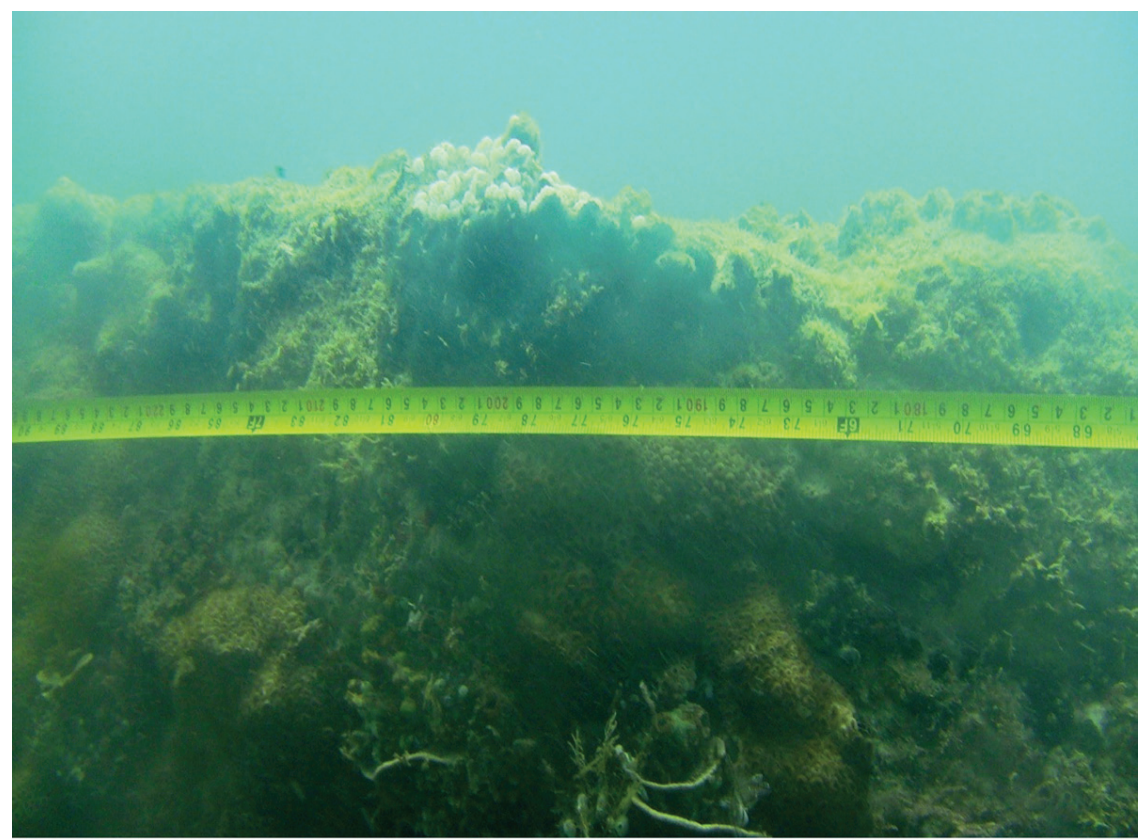

Figure 2. A section of underwater wall in would-be Rhapta. (Photo by Caesar Bita underwater archaeologist from Kenya Museum) 


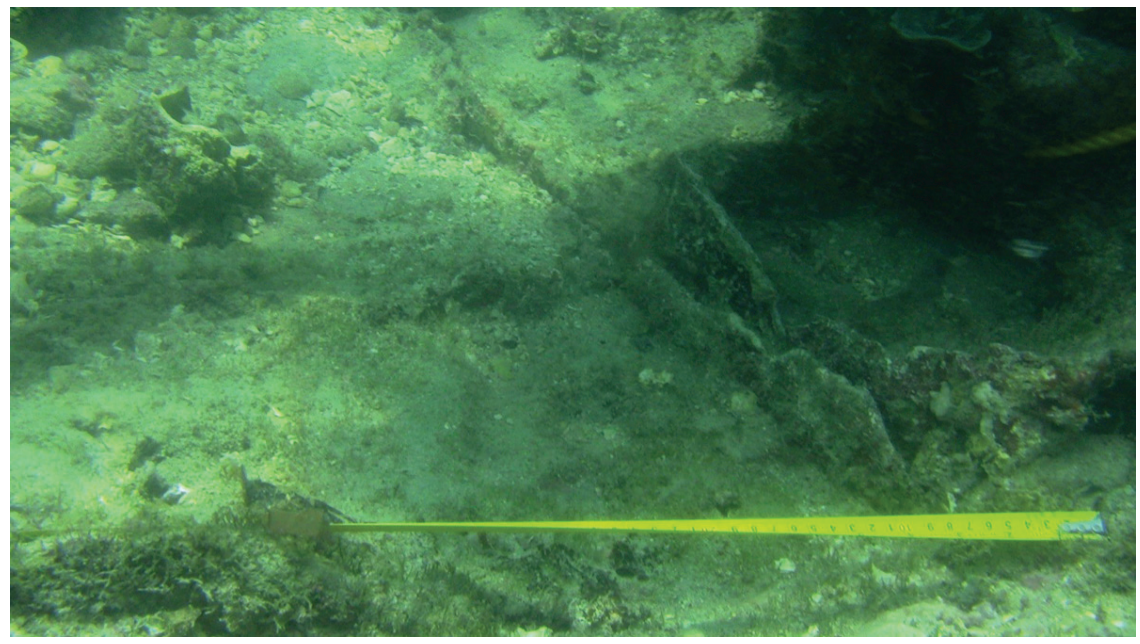

Figure 3: Underwater structures with right single joints, probably Rhapta houses. (Photo by Caesar Bita underwater archaeologist from Kenya Museum)

soil (Casson 1980) the other clear indicator of the kind of people is that, according to the map of Claudia Ptolemy, the people at the Rhapta area were Rafiji Ethiopes. It should be noted here that Ethiopes in the ancient Roman time meant black people (Lacroix 2017). It should also be noted that the Greek reports of the three hundred years before the Christian era did also report about the people of the coast of East Africa, which was then known as Panchea, having been tillers of soil (Chami 2004: 95; Diodurus, et al. 1961).

\section{Some Controversies}

There are some controversies on the types of people settling in Azania and hence on the location of Azania and its metropolis.

The debate was sparked off by the translation of the document of the Periplus by Lionel Casson (1969) who refused the translation by his predecessors of the Latin word orotai to mean that the people of Azania were pirates. Casson (1969) translated this as cultivators or tillers of the soil. Several scholars agreed with the earlier translation arguing that the people of Azania were Hamites or Cushites. This Hamitic thinking was hastily accepted by scholars since it had been an ideology since colonial times that it was Cushites who brought Neolithic and civilisation to Africa (for conspectus, see Seligman 
1930). To understand the origin and the essence of this theory, see the review by Edith Sanders (1969).

For the coast of East Africa, James de Vere Allen (1993) had already developed a thought that the earliest civilisation of the coast of East Africa had been developed by Cushites who were first based on the northern Kenya coast close to Somalia. Concerning the people of Azania having had been cultivators and hence Bantu speakers as put by Casson. Horton picked up from Allen by arguing that:

The early - first - first-century date of Periplus, and the implication of a population settled for a considerable time on the coast and in commercial contact with the Red Sea, would appear to rule out early - iron Age Bantu communities (Horton 1990: 96).

Horton's idea was supported by other scholars such as John Sutton who argued that the Azanians were "Cushitic - speakers" (Sutton 1994-5: 231). As discussed by this author (Chami 2001), Christopher Ehret dramatised the idea of Cushitic colonisation of eastern and southern Africa probably more than anyone else in recent time. He argued that Rhapta was settled by southern Cushites. He attributed the sites of Bambata in Zimbabwe and Salumano in Zambia to southern Africa to the Southern Cushites (Ehret 1998: 217). With this Cushitic ideology, many scholars were also influenced to think that Azania and its metropolis would have had been located more to the northern coast of East Africa close to Cushitic influence (Allen 1993).

I did disagree with this Hamitic/Cushitic myth ideology in 1990s. In 'The First Millennium A.D. on the Tanzanian Coast' (Chami 1994), I argued that the civilisation of the whole Swahili coast had a foundation in the civilisation of the people of the Early Iron Age who archaeologists and linguists had identified as Bantu speakers (Huffman 1970;; Soper 1971). It was after 1994, when I discovered many sites of the Early Iron Age on the coast of Central Tanzania and to the islands of the Indian Ocean, that the Cushitic myth fell asunder (Chami and Msemwa1997). Many scholars, including the advocates of the Cushitic myth, changed their mind to accept that Azanians were Bantu speakers (Haaland and Msuya 2000; Horton and Middleton 2000; Pouwels 1999; Spear 2000; Sutton 1998; see also Horton and Chami 2018). 


\section{Discussion}

It was previously noted that the exact ancient cultural core of Azania is placed on the coast of East Africa, southern Somalia being to the north and the southern coast of Tanzania on the south. It should be reiterated that this issue has well been discussed by several scholars (Casson 1969: Datoo 1970; Huntingford 1980; Kirwan 1986). I previously noted about the Cushitic mythology and scholars who have preferred Rhapta, the capital of Azania, and Azania itself to be placed on the northern coast of East Africa near the Somalia region to allow the territory and its metropolis to be near the Cushitic territory of Somalia. It has been a colonial legacy to put any ancient mentioned civilisation of the Eastern region of Africa in the regions of either Somalia or even Ethiopia. That is how the Egyptian land of Punt and the Greek land of Panchea, which were predecessors of Azania, have been placed by most scholars (for conspectus, see Carry and Warmington 1963; Kitchen 1971; Kitchen 1993;). My colleague and I have provided the most recent view of the ancient location of those territories (Chami 2004; Chami and Ntandu 2018; Chami forthcoming, also see perry 2005 and Kitchen 2004).

As it pertains to Azania, some scholars, including Neville Chittick (1982), David Phillipson (2005: 262), W. F. G. Lacroix (1998), and Chami (2006, 2017, have considered the Rufiji River area on the central coast of Tanzania as the most preferable place for the location of Rhapta. Lacroix (1998) has probably provided the most recent discussion of the location of Azania and the locations of its metropolis of which the region of modern East Africa is the one preferred by him. It is also obvious that the geography of Claudia Ptolemy, which also provides a map of Africa, places Azania in the region of East Africa and Rhapta at a riverbank at latitude 7 to 8 degrees which is exactly at the Rufiji River on the central coast of Tanzania (Freeman-Greenville 1962 Lacroix 1998).

Did Azania extend geographically and culturally beyond the coast of East Africa? It is my view that this problem has not properly been addressed academically. It is, however, very interesting to know that the people of South Africa have been naming themselves as Azanians (https://face2faceafrica.com/article/south-africa-Azania). It is my view that historical and archaeological data can be used to provide a parsimonious answer to this problem. 
There are few points in the ancient historical records which can be used to help solve this problem.

The first is the report that some individuals who visited Azania from the Roman world such as Theophilus and Dioscorus did also pay a visit to the territory south of the core of Azania, as far south as the Mozambican channel (Carry and Warmington 1963). Dioscorus is said to have surpassed Theophilus in this kind of visitations probably meaning that he did it several times or he even went beyond the channel. It will be shown later in this article that Madagascar and Comoros may also have been visited occasionally as the Map of Ptolemy has all the islands on it (Lacroix 1998 Map. 8).

It will be noted in this article that sites of the Early Iron Age have been found in Comoros (Figure 4). Since the Chinese also reported

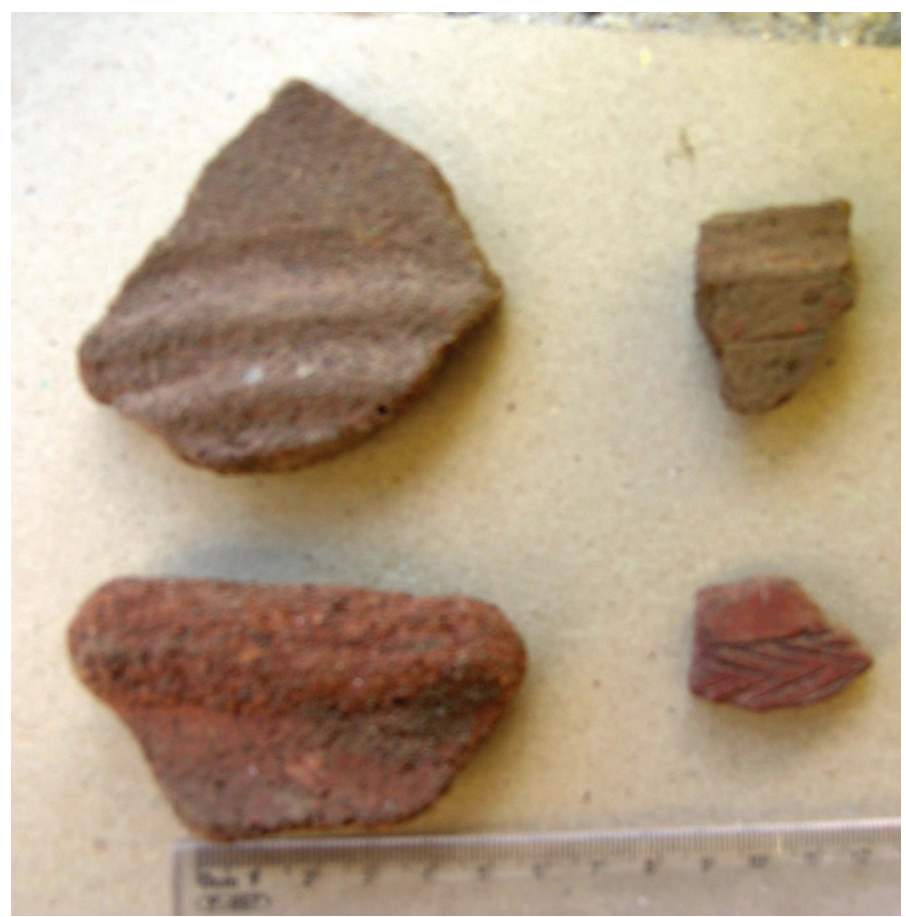

Figure 4. Showing Early Iron Age pottery from Comoros similar to those found in Silver leaves in South Africa (see later in this article) and on the coast of Tanzania (for illustration, see Chami 2011). Top two shards are bevelled, the bottom left has a flute on the rim, and the bottom right has herringbone decoration all decorative attributes being typical to Early Iron Age pottery of the region of East Africa. 
to have sailed to the southern Africa region to circumnavigate the African continent (see earlier in this article), it is obvious that they must have obtained the information about South Africa from the Azanians themselves who, it would seem, had both trade and cultural connections to it (see further in this article). The Romans seem not to have known much about South Africa since they thought that Africa turned to the east in the south making the Indian Ocean look like a great lake or a sea (Carry and Warmington 1963).

The second historical point is about a possible geographical extension of Azania to the Great Lakes region. The report is that of one Roman skipper by the name of Diogenes who visited Azania from the Roman world. He travelled from the coast of Azania to the deep interior of East Africa for reasons not clearly stated. In his visit or visits he saw a mountain with three snowy peaks, obviously being Mount Kilimanjaro (Stahl 1965). He reached the Great Lakes region where he saw a mountain he termed the mountain of the Moon which provided water to a great lake that was the source of the Nile. Diogenes saw Ruwenzori Mountain and the River Kagera which provides water to Lake Victoria as the source of the Nile. I have argued elsewhere that this skipper must have followed a caravan trade route which must have been used to ply goods between the two regions of East Africa or Azania (Chami 1999a; Chami and Ntandu 2018).

Two good Roman historical reports are supporting this second historical connection. The first is that of Elder Pliny, previously mentioned, who stated that spices were obtained from the cave dwellers on the coast and transported to the deep interior of Azania and then ferried to the north following the Nile. The second support is that of the Roman Caesar Nero's demand for the verification of an existing trade route following the Nile from Azania. The king was informed that the route had gone into crisis after the Romans opened the Azania Indian Ocean route through the Red Sea (Synge 1938; Welsby1996).

There are also several archaeological data that can be used to argue that Azania may have had extended to the Great Lakes region and Southern Africa. The first point is the archaeological find of sites of the Early Iron Age or the Roman period with similar cultural materials spread in the whole of east, central, and southern Africa. This cultural tradition was of people who were smelting iron 
and using similar pottery which came to be known as the Early Iron Age pottery (Figure 4). These were also found to be agriculturalists.

The premise for this first archaeological data was the theory advanced from 1960or so by archaeologists that the pottery (previously mentioned), which is of the first four centuries of the Roman period or $\mathrm{CE}$, was the best indicator of the existence of the Bantu speakers in the region of the Eastern Africa to Southern Africa (Phillipson 1976, 2005).

Linguists were also of the same view that these ancient people spoke one language known as Bantu, and they were agriculturalists like the Bantu speakers of modern times (Greenberg 1955; Guthrie 1970). This was also the pottery of the Azanian people (Phillipson 2005: 252) the pottery of that Azania period was also known by different names viewed as variants of that cultural tradition (Soper 1971a). On the coast of East Africa, this pottery was given the name of Kwale. It is this variant that its people are thought to have had migrated to southern Africa as an alleged eastern stream of Bantu speakers migration (see later in this article). Most archaeologists and linguists agreed that Bantu speakers did spread in the larger region of eastern, central, and southern Africa with their origin put as far northwest as the Cameroonian Chad area where the earliest dispersal occurred (Phillipson 1976, 2005). It is also agreed that a next dispersal occurred in the Great Lakes region particularly in the Lake Victoria area after the carrying capacity of the land was low. The Bantu speakers are at this juncture thought to have had spread to the whole region in three streams (Huffman 2007; Phillipson 1976 2005; Sopper 1971a).

Whereas scholars of this Early Iron Age tradition banked on migration as the method to explain how the Bantu speakers occurred in the large region of eastern, central, and southern Africa, I have questioned this theory which I term 'locust kind' of people's movement by proposing in lieu that the Bantu speakers had been in the previously mentioned three regions from the time of the early farming period, in the Neolithic period or even before as now vindicated in the Kuumbi cave excavations in Zanzibar (Chami 2009b; Sinclair et al. 2006). In this opinion, I have echoed Richard Gramly (1978) and Gramly and G. Philip Rightmire (1973) who proposed that the Neolithic people of the region were not Cushites but Bantu speakers. This was also the position of Harold Ingrams (1962). I have 
also elucidated this point in my recent publications (Chami 1999a, 2006, and forthcoming). I argue that what is seen as Bantu migration is a cultural similarity of artefacts which was caused by trade or cultural connections which involved caravan-like trade routes of which a realistic model would be the nineteenth-century Swahili trade missions to as far as central Africa which made Islamic culture and the Swahili language spread to the deep interior of the coast of East Africa as far as Congo in central Africa, and Zimbabwe in southern Africa without actual immigration of the Swahili people (Chami 1999a; Chami and Ntandu 2018). In the same manner as Zanzibar in the nineteenth century, the metropolis of Rhapta and Toniki in Azania acted as gateway communities in the manner proposed by other scholars (Dalton 1975; Renfrew 1977).

The second archaeological point supporting a possible extension of Azania to southern Africa is the actual find of coins and materials of trade in Southern Africa itself, similar to those found in East Africa from the civilisations of the north suggesting trade connections (Horton 1996). Probably another important and third archaeological point which can be used to pin South Africa to Azania in ancient times has been the find of Kwale variant pottery in Natal and Transvaal. The sites with this pottery also provided carbon-14 dates similar to those of Kwale sites in East Africa (Chami 2006: 127; Klapwijk 1974). Klapwijk and Huffman (1979) reported the cultural affinity of this South African pottery to those of East Africa. This pottery affinity could influence one to argue that the people of the two regions were in connection to one another through trade or some other kind of cultural connections. It is this strong cultural affinity about which Klawijk (1974: 22) argued that it is more probable that Kwale pottery makers came down the coast by ship or either as migrants or as slaves'.

Whereas sailing to South Africa for trade or as immigrants is easily conceivable and can be demonstrated academically, as previously shown, the question I posed in 2006 was, who would have taken the Azanians from East Africa to South Africa as slaves? There is no evidence of the Roman or other foreigners settling in South Africa in ancient times enslaving Azanians.

Probably it is more parsimonious to use this evidence of strong cultural affinity between Southern Africa and East Africa in ancient times as good support of the Azanians' cultural and trade extension 
to South Africa. I have previously noted the most recent connections of the Swahili people with the other people of central and southern Africa. Let me strengthen this point here by noting that during the nineteenth-century European exploration missions in eastern and central Africa, the explorers followed well-known trade routes, and they were led by the Swahili skippers some of whom led other explorers like Speke to Egypt following the Nile. Stanley was led to the Atlantic and made to sail via the southern cape to East Africa (Simpson 1975). It is not bizarre to think that the same phenomenon first occurred in ancient times with the Romans. Surprisingly, what the nineteenth-century Europeans were trying to discover in eastern and central Africa had already been reported by the Romans (Chami and Ntandu 2018)

A fourth archaeological point in connection to the extension of Azania to southern Africa is a reiteration of the point raised differently earlier that research on the islands of the Eastern African Indian Ocean seaboard from Zanzibar to Madagascar portrays sailing by the Early Iron Age people and their predecessors in ancient times concerning the finding of archaeological sites of that period thither (Chami 2011; Rasolondrainy 2012 Wright 2018). These findings work against the racist colonial paradigm that the Bantu speakers could not sail in the past (Sheriff 1981).

Archaeological, linguistic, and historical evidence is enticing one to argue that the people of the whole region settled by Bantu speakers in eastern as far as southern Africa were Azanians in the manner of the near modern and the medieval period Swahili control of the larger region (Chittick 1974; Pikirayi 1993; Posnansky 1975;). It is in the manner of the modern-day SADEC countries' political and military organisation.

Surprisingly archaeologists already conceived a model to solve the problem of location and geographical extension of Azania. They launched a research project in the 1960s which they coined the Bantu project for research to cover the whole theorised Azanian region of eastern, central, and southern Africa. Targeted sites for research were those of the Early Iron Age/the Roman period previously noted and those of the Neolithic tradition which, as previously noted, some scholars already recognised as belonging to the same Bantu speakers. The journal which was launched to publish research results of this project was very correctly given the name of Azania (Soper 1971b). 
It should be pointed out at this juncture that the regions of eastern and southern Africa has had many people who are different from Bantu speakers (Seligman 1930). I have hypothesised their earliest appearance in these regions of Africa elsewhere (Chami 2006). If Azania did connote large regional trade connections, then for sure people of different ethnicities would have been involved. On his map, Ptolemy recognises the people of this large region as Ethiopies. It is not clear if other people different from Bantu speakers were also viewed as black.

Strabo who also wrote in the Roman period a bit before Pliny did report that all the voyagers who attempted to sail from the Red Sea to the regions of eastern and southern Africa reported that all the people they met were Ethiopes or black people, as previously noted (Strabo and Jones 1960). Unfortunately, only two ethnic groups mentioned on the Map of Ptolemy can be recognised today. It was noted earlier that the Rufiji people living today on the Delta region of the Rufiji River of the central coast of Tanzania are shown on the same region of the map as Rafiji Ethiopes.

On the southern coast of eastern Africa on Mozambican/Zimbabwe area were put Agysimba Ethiopes. We hear today about people with a similar name in Madagascar offshore Mozambique. In the sixteenth century, the Portuguese reported about black people with a similar name from Mozambique ravaging the town of Kilwa and other Swahili towns (Freeman-Grenville 1962). Lacroix has discussed the actual location of Agysimba in ancient times, and he proposes central Africa as the possible location indicated by Ptolemy (Lacroix 1917). However, in his previous publication, he put these people on the Mozambican coast (Lacroix 1998 map 8.).

\section{Conclusion}

Banking on the historical, archaeological, and linguistic data presented in this article, one could argue that the region of Africa visited by the Romans and the Chinese in the ancient time which the Romans recorded as Azania and the Chinese as Zesan could have extended from its core on the coast of East Africa to the Great Lakes region and to southern Africa. It has been stressed above that the Swahili civilisation of the coast of East Africa with its core 
on the same area of Azania did replicate what the Azanians did by extending its influence to southern and central Africa and the Great Lakes regions of Africa. Surprising in modern times, Mwalimu Julius Nyerere of Tanzania at the ancient core of Azania and the Swahili civilisation did argue that the people of Tanzania will not be free until the other people of central and southern Africa are also free. It is this view that has created a modern Azania territory under the name of SADEC. It is also under this argument that the people of the large region can name themselves Azanians.

\section{Acknowledgement}

I thank Dr Ndumiso Dladla for requesting me to author this article and for even suggesting the title for it. He worked hard to see this article submitted to this journal for review work. I thank Dr Christowaja Ntandu and Mr Ceasor Bita for taking photos of the features of the underwater site at Mafia Island shown in this article.

Felix A. Chami was born in Kilimanjaro, Tanzania, in 1958. He studied for his BA degree at the university of Dar-es Salaam, Tanzania, and for his MA at Brown University, USA, and for his $\mathrm{PhD}$ at Uppsala University, Sweden. He is a full professor of history, heritage, and archaeology at the University of Dar-es Salaam, Tanzania. He is a member of the Re-centring AfroAsiatic project. His current research is on the ancient settlements of the coast of East Africa and on the peopling of the slopes of Mount Kilimanjaro. E-mail: fchami@udsm.ac.tz

\section{References}

Allen, J. 1993. The Swahli Origin. London: James Curry.

Carry, M. and E. Warmington. 1963. The Ancient Explores. Middlesex: Penguin Books.

Casson, L. 1980. 'Periplus Maris Erythreai: Three Notes on the Text'. Classical Quarterly 30: 2495-2497. DOI: https://doi.org/10.1017/S0009838800042415 Casson, L. 1989. Periplus Maris Erytraei. Princeton: University Press.

Chami, F. 1994. Tanzanian Coast in the First Millennium A.D. Uppsala: Upssaliensis. 
Chami F. 1994. 'The First Millennium A.D. on the East Coast: A New Look at the Cultural Sequence and Interactions' Azania 29-30: 227-237.

Chami, F. 1998. 'A Review of Swahili Archaeology'. African Archaeological Review 15 (3): 199-218.

Chami, F. 1999a. 'Greaco-Roman Trade Link and the Bantu Migration Theory'. Anthropos 94 (1-3): 205-215.

Chami, F. 1999b. 'Roman Beads from the Rufiji Delta Tanzania: First Incontrovertible Archaeological Link with the Periplus'. Current Anthropology 40 (2): 237-241.

Chami, F. 2001. 'A Response to Christopher Ehret's Bantu expansion', International Journal of African Historical Studies 34 (3): 647-651.

Chami, F. 2004. 'The Egypto-Greaco-Romans and Panchea/Azania: Sailing in the Erythrean Sea'. In P. Lund and A. Porter (eds), Red Sea Project 1; Trade and travel in the Red Sea Region: Proceedings of Red Sea Project 1. British Archaeological Reports, 1269: 93-104.

Chami, F. 2006. The Unity of African Ancient History 300 B.C. to A.D. 500. Dar-es-Salaam: E\&D Vision Publishers.

Chami, F. (ed.). 2009b. Zanzibar and the Swahili Cost from 30000 Years Ago. Dar-es-Salaam: E \& D Vision.

Chami, F. 2011. 'Archaeological Research in Comores between 2007 to 2009'. In C. Radimilahy et al. (eds.), Civilizations des Mondes Insulaires:Melanges en l'honneur du Profeseur Claude Allibert. Paris: Karthala, 811-823.

Chami, F. 2017. 'Ancient Seafaring in Eastern African Indian Ocean Waters'. In P. De Souza (ed.) The Sea in History: Antiquity. London: Boydell \& Brewer, 523-535.

Chami, F. Forthcoming. 'The Advent of Domestication in Eastern and Southern Africa'. In A. Holl (ed.), General History of Africa, Vol. 9. Paris: UNESCO.

Chami, F. and Msemwa, P.1997. "A new look at culture and trade on the Azanian coast”. Current Anthroplogy. 38(4):673-677.

Chami, F. and C. Ntandu, 2018. 'East Africa in Classical Times: Reconstructing Past Networks between the Coast and Interior'. In A. Ekblom et al. (eds.), Climate Change and Scale. Uppsala: Uppsaliensis, 307-323.

Chittick, N. 1974. Kilwa: Islamic Trading City on the Coast of East African Coast. Nairobi: British Institute in Eastern Africa.

Chittick, N. 1975. 'The Peopling of the East African Coast'. In N. Chittick and R. Rotberg (eds.), East Africa and the Orient: Cultural Synthesis in Precolonial Times. New York: Africana, 16-43.

Chittick, N. 1982. 'Reconnaissance in Coastal Tanzania', Nyame Akuma 20: 65-75.

Dalton, G. 1975. 'Karl Polanyi's Analysis of the Long-Distance Trade and His Wider Paradigm'. In J. Sabbloff and C. C. Lamberg-Karlovsky (eds), Ancient Civilization and Trade. Albuquerque, NM: University Press, 63-132.

Datoo, B. 1970. 'Rhapta: The Location and the Importance of East African's First Port', Azania 5: 65-75. 
Diodurus, S., et al. 1961. Diodorus of Sicily(12 volumes). London: William Heinemann.

Ehret, C. 1998. An African Classical Age. Oxford: The University of Virginia Press.

Freeman-Grenville, G. 1962. The East African Coast: Selected Documents from the First to the Earlier Nineteenth Century. Oxford: Claredon Press.

Gramly, R. 1978. 'Expansion of Bantu Speakers Versus Development of Bantu Language in Situ: An Archaeologist's Perspective'. South African Archaeological Bulletin 33: 107-112.

Gramly, R. and G. Rightmire. 1973. 'A Fragmentary Cranium and Dated Later Stone Age Assemblage from Lukenya Hill, Kenya', Man 8: 571-579.

Greenberg, J. 1955. Studies in African Linguistic Classification. New Haven, CT: The Compass Publishing Company.

Gupta, S. 2016. 'Contact between East Africa and India in the First Millennium C.E.'. In G. Campbell (ed.), An Early Exchange between Africa and the Wider Ocean World. Montreal: Palgrave Macmillan, 157-171.

Guthrie, M. 1970. 'Some Development in the Prehistory of the Bantu Languages'. In J. Fage and R. Oliver (eds.), Papers in African Prehistory. Cambridge: Cambridge University Press. 131-140.

Haaland, R. and C. Msuya. 2000. 'Pottery Production, Ironworking, and Trade in EIA: The Case of Dakawa, East Central Tanzania', Azania 35: 75-106.

Hill, E. (transl). 2004. The Peoples of the West from the Weilue by Yu Huan in 429 C.E. http://depts.Washinton.ed/uwch/silkrad/texts/weilue/weilue.html.

Horton, M. 1984/1996. 'The Early Settlement of the Northern Swahili Coast'. PhD diss., 'The Archaeology of a Muslim trading community on the coast of East Africa'. London: British Institute in Eastern Africa.

Horton, M. 1990. 'The Periplus and East Africa', Azania 25: 95-99.

Horton, M. 1996.'Early Maritime trade and settlement along the coasts of eastern Africa". in J. Reade (ed), Ocean in Antiquity, 439-560, London. Keagan Paul.

Horton, M. and F. Chami. 2018. 'Swahili Origin'. In S. Wynne-Jones and A. Laviolette (eds), The Swahili World. London: Routledge, 135-147.

Horton, M. and J. Middleton. 2000. The Swahili. Oxford: Blackwell.

Huffman, M. 1970. "The early Iron Age and the spread of the Bantu." South African Archaeological Bulletin 25: 3-21.

Huffman, T. 2007. Iron Age: The Archaeology of Pre-colonial Farming Societies in Southern Africa. Pietermaritzburg: The University of Kwa-Zulu Natal Press.

Huntingford, G. 1980. The Periplus of the Erythrean Sea. London: The Hakluyt Society.

Ingrams, H. 1962. Zanzibar: Its History and its People. London: Wotherby.

Kirwan, L. P. 1986. 'Rhapta, Metropolis of Azania', Azania 21: 99-114.

Kitchen, K. 1971. 'Punt and How to Get There'. Orientalia 40 (2): 184-192.

Kitchen, K. 1993. 'The Land of Punt'. In T. Shaw, P. Sinclair, B. Andah and A. Okpoko (eds), The Archaeology of Africa: Food, Metals and Towns. London: Routledge, 587-606. 
Kitchen, K. 2004. 'The Elusive Land of Punt Revisited'. BAR International Series 1269: 25-33.

Klapwilk, M. 1974. “Apreliminary report on pottery from the north-eastern Transvaal , South Africa," South African Archaeological Bullettin 29(113114):84-93.

Klapwijk, M. and Huffman, T. 1996. "Excavations at SilverLeaves: A final report." Southern African Archaeological Bullettin 51(164)): 84.

McLaughlin, M. 2018. The Roman Empire and the Indian Ocean. Yorkshire: Pen \&Sword.

Miller, J. 1969. The Spice Trade of the Roman Empire. 29 B.C. to A.D. 641. Oxford: Clarendon Press.

Perry, C. 2005. Egypt: Land and Lives of the Pharaohs Revealed. Hongkong: Global Book Publishing.

Phillipson, D. 1976. 'Early Iron Age in Eastern and Southern African: Critical Re-appraisal'. Azania 7 (11): 1-23.

Phillipson, D. 2005. African Archaeology. Cambridge: Cambridge University Press.

Pikirayi, I. 1993. The Archaeological Identity of the Mutapa State: Towards Historical Archaeology of Northern Zimbabwe: Studies in African Archaeology 6. Uppsala: Societas Upsaliensis.

Pliny/Rackam, H. (ed. and trans1.). 1961. Natural History(10 volumes) London: William Heinemann.

Posnansky, M. 1975. 'Connections between the Lacustrine Peoples and the Coast'. In N. Chittick and R. Poberg (eds), East Africa and the Orient. New York: Africana Publishing, 129-154.

Pouwels, R. L. 1999. 'East African Coastal History', Journal of African History 40 (2): 285-296.

Rasolondrainy, T. 2012. 'Discovery of Rock Paintings and Libyco-Berrber Inscription from the upper Onilahy, Isalo Region, Southwestern Madagascar', Studies in the African Past 10: 173-195.

Renfrew, C. 1977. 'Alternative Models for Exchange and Spatial Distribution'. In T. Earle and J. Ericson (eds.), Exchange Systems in Prehistory. London: Academic Press, 71-90.

Sanders, E. 1969. 'The Hamitic Hypothesis: Its Origin and Function in Time Perspectives', The Journal of African History 10 (4): 521-532.

Schoff, W. 1912. The Periplus of the Erythrean Sea. New York: Longmans.

Seligman, C. 1930. The Races of Africa. London: Oxford: University Press.

Sheriff, A. 1981. 'The East African Coast and the Role of Maritime Trade'. In G. Moktar (ed.), General History of Africa: Ancient Civilization of Africa, vol 2. Berkley, CA: UNESCO, 551-567.

Shikoni, A. D., et al. 2019. 'Preliminary Report of the Re-excavation of Ukunju Limestone Cave in Juani, Mafia Archipelago, Tanzania: More Evidence of Ancient Transoceanic Trade Connections'. Man and Environment XLIV (2): 29-40. 
Simpson, D. 1975. Dark Companions: The African Contribution to the European Exploration of East Africa. London: Paul Elek.

Sinclair, P. 2007. 'What Is the Archaeological Evidence for Coastal Trading Contacts on the East African Coast in the First Millennium B.C.'. BAR International Series 1661: 187-194.

Sinclair, P., A. Juma, and F. Chami. 2006. 'Excavations at Kuumbi Cave Zanzibar'. In J. Kinahan and J. Kinahan (eds), The African Archaeology Network: Research in Progress. Windhoek: Capital Press. 95-107.

Soper, R. 1971a. 'A General Review of Early Iron Age of the Southern Half of Africa', Azania 5: 39-52.

Soper, R. 1971b. 'Bantu Project', Azania 5: 1-4.

Spear, T. 2000. 'Early Swahili History Reconsidered', The International Journal of African Historical Studies 33 (2): 257-290.

Stahl, K. 1965. 'Outline of Chaga History'. Tanganyika Notes and Records 64: 35-49.

Strabo/Jones, H. (ed. and trans). 1960. The Geography of Strabo, Volume 1. London: Williams Heinemann.

Sutton J. 1994-5 "East Africa : interior and coast.” Azania 94-30:227-232.

Sutton, J. 1998. 'Kilwa'. Azania 33: 113-169.

Synge, P. 1938. Mountains of the Moon. London: Lindsay Drummond.

Triminghan, J. 1975. 'The Arab Geographers and the East African Coast'. In N. Chittick and R. Rotberg (eds), East Africa and the Orient. New York: Africana Publishing, 115-146.

Welsby, D. 1996. The Kingdom of Kush. London: British Museum Press.

Wright, H. 2018. 'Comoros and Their Early History'. In S. Winne-Jones and A. Laviolette (eds.), The Swahili World. London: Routledge, 266-277. 